\title{
The Application Of Mind Mapping Learning Method To Improve Writing Skills Of Summary About Technology Development Themes
}

\section{Desi Martina}

Universitas sebelas Maret

desi.martina27@gmail.com

\section{Article History}

received 30/4/2021

\begin{abstract}
The application of the method has an important effect on the achievement of learning competencies, especially in the aspects of knowledge and skills. The low writing skills of students can be influenced by the inappropriate application of learning methods. The purpose of this study is to determine the success of the application of the mind mapping method in improving summary writing skills, and to describe the application of the mind mapping method to the improvement of writing skills summary of the theme of technological development in third grade students of SDN Gebang 2 Sukodono for the 2020/2021 academic year. This research is a quantitative research with correlational method. Data collection techniques using documentation techniques, interviews, tests, and observations. The validity of the data using triangulation of sources and techniques. Data analysis through reduction, data presentation, and drawing conclusions. Based on the analysis and discussion of the research results, there was an increase in the average value from 50.00 to 80.00 , and the initial completion percentage of $10 \%$ increased to $90 \%$. So it can be concluded that the application of the mind mapping method can improve the summary writing skills of class III students on the theme of technology development at SD Negeri Gebang 2 Sukodono in academic year of 2020/2021.
\end{abstract}

Keywords: Mind mapping, summary writing skills

\begin{abstract}
Abstrak
Penerapan metode berpengaruh penting dalam ketercapaian kompetensi pembelajaran, terutama pada aspek pengetahuan dan keterampilan. Rendahnya keterampilan menulis peserta didik dapat dipengaruhi karena ketidaktepatan penerapan metode pembelajaran. Tujuan penelitian ini yaitu mengetahui keberhasilan penerapan metode mind mapping dalam meningkatkan keterampilan menulis ringkasan, dan mendeskripsikan penerapan metode mind mapping terhadap peningkatan keterampilan menulis ringkasan tema perkembangan teknologi pada peserta didik kelas III SDN Gebang 2 Sukodono tahun ajaran 2020/2021. Penelitian ini merupakan penelitian kuantitatif dengan metode korelasional. Teknik pengumpulan data menggunakan teknik dokumentasi, wawancara, tes, dan observasi. Validitas data menggunakan triangulasi sumber dan teknik. Analisis data melalui reduksi, penyajian data, dan penarikan simpulan. Berdasarkan analisis dan pembahasan hasil penelitian terjadi peningkatan nilai rata-rata yang awalnya 50.00 menjadi 80.00 , dan persentase ketuntasan awal $10 \%$ naik menjadi 90\%. Maka dapat disimpulkan bahwa penerapan metode mind mapping dapat meningkatkan keterampilan menulis ringkasan peserta didik kelas III tema perkembangan teknologi SD Negeri Gebang 2 Sukodono Tahun Ajaran 2020/2021.
\end{abstract}

Kata kunci: mind mapping, keterampilan menulis ringkasan 


\section{PENDAHULUAN}

Pendidikan merupakan upaya untuk mencapai tujuan pendidikan. Tujuan pendidikan nasional menurut Sistem Pendidikan Nasional dalam Undang-Undang Nomor 20 Tahun 2003 yaitu mengembangkan segala potensi yang dimiliki oleh setiap individu guna menjadi manusia berilmu, beriman, serta berakhlak mulia. Pengembangan potensi tersebut sebaiknya dilakukan sejak pendidikan dasar. Kualitas proses pembelajaran mempengaruhi kualitas pendidikan dan pencapaian kompetensi pembelajaran oleh peserta didik. Pemilihan dan penerapan strategi, model, atau metode pembelajaran berpengaruh penting dalam ketercapaian kompetensi pembelajaran, terutama pada aspek pengetahuan dan keterampilan. Keterampilan menulis peserta diidk rendah dapat dipengaruhi karena tidak tepatnya metode pembelajaran yang dipilih atau diterapkan guru dalam kegiatan proses pembelajaran.

Iskandarwassid dan Sunendar (2011) menyatakan bahwa metode pembelajaran adalah cara kerja yang sistematis untuk memudahkan pelaksanaan berbagai kegiatan pembelajaran untuk mencapai tujuan yang diinginkan atau ditentukan. Pemilihan dan penerapan berbagai metode pembelajaran perlu disesuaikan dengan karakteristik materi, muatan pelajaran, serta karakteristik peserta didik agar mampu mencapai kompetensi pembelajaran secara maksimal. Maka dari itu guru harus terus mengembangkan kompetensi professional serta pedagogiknya agar mampu merancang dan melaksanakan kegiatan proses pembelajaran yang berkualitas dengan pencapaian kompetensi yang maksimal.

Keterampilan menulis menjadi salah satu fokus dari empat keterampilan berbahasa di samping keterampilan menyimak, membaca, dan berbicara. Menulis merupakan keterampilan berbahasa yang produktif dan ekspresif, yang dipergunakan untuk berkomunikasi secara tidak langsung. Menulis merupakan aktivitas untuk mengungkapkan kembali berbagai gagasan atau pengalaman yang pernah dialami dan dibaca pada waktu lampau, direkonstruksi ulang dan disusun menjadi sebuah tulisan. Menurut Sukartiningsih dkk (2013) Keterampilan menulis adalah kecakapan dalam melahirkan pikiran atau perasaan dalam bentuk karangan atau membuat cerita. Sedangkan ringkasan menurut Alfaini (2011) merupakan penyajian singkat dari suatu karangan asli, sedangkan perbandingan bagian atau bab dari karangan asli secara proposional tetap dipertahankan dalam bentuknya yang singkat.

Buzan (2011) menyatakan bahwa mind mapping adalah cara mencatat yang kreatif, efektif dan secara harfiah akan memetakan pikiran-pikiran peserta didik. Peta Pikiran juga berguna untuk: (1) meringkas informasi; (2) konsolidasi informasi dari sumber-sumber penelitian yang berbeda; (3) memikirkan masalah yang kompleks; dan (4) menyajikan informasi dalam format yang menunjukkan struktur keseluruhan subjek Anda sebagai jenis diagram mafinitas. (https://www.dosenpendidikan.co.id/mindmapping-adalah/).

Menurut hasil penelitian Dinda Ayu Septiani (2019) menunjukkan adanya peningkatan keterampilan menulis ringkasan siswa kelas IV B SDN Cemorokandang 2 Kota Malang melalui penerapan model pembelajaran mind mapping. Dari data penelitian tersebut diperoleh hasil rata-rata nilai peserta didik dalam menulis ringkasan terus meningkat tiap siklus yaitu dari 44,15 menjadi 61,25 pada siklus I, dan 77.05 pada siklus II, selain itu perolehan persentase ketuntasan klasikal juga mengalami peningkatan dari $10 \%$ pada pra siklus, $50 \%$ pada siklus I, dan $80 \%$ pada siklus II.

Berdasarkan hasil observasi pra-siklus yang dilaksanakan pada Senin, 22 Februari 2021 terhadap peserta didik kelas III di SD Negeri Gebang 2 tahun pelajaran 2020/2021 Tema Perkembangan Teknologi diperoleh kemampuan menulis ringkasan peserta didik masih rendah. Hal ini terbukti dari rata-rata persentase pada tiap-tiap indikator keterampilan menulis peserta didik kelas III yaitu 1) kemampuan untuk menemukan masalah yang akan ditulis sebesar $40,00 \%$, 2) kemampuan menggunakan bahasa sebesar $20,00 \%$, 3) kemampuan memulai menulis sebesar $40,00 \%$, dan 4) 
kemampuan memeriksa karangan sendiri sebesar 30,00\%. Selain itu berdasarkan hasil belajar Tema 7, peserta didik diperoleh data pra siklus, rata-rata hasil belajar peserta didik 50,00 dengan persentase 10,00\%. Dari data tersebut dapat kita ketahui bahwa kemampuan menulis ringkasan peserta didik masih dalam kategori rendah. Berdasarkan permasalahan yang penulis temukan di lapangan, maka dapat dirumuskan masalah sebagai berikut: "Apakah penggunaan metode mind mapping dapat meningkatkan keterampilan menulis ringkasan tema perkembangan teknologi pada peserta didik kelas III SD Negeri Gebang 2 Kecamatan Sukodono Kabupaten Sragen tahun ajaran 2020/2021?"

Berdasarkan uraian di atas tujuan penelitian ini yaitu untuk mengetahui keberhasilan penerapan metode mind mapping dalam upaya meningkatkan keterampilan menulis ringkasan, dan mendeskripsikan pengaruh penerapan metode mind mapping terhadap peningkatan keterampilan menulis ringkasan tema perkembangan teknologi pada peserta didik kelas III SDN Gebang 2 Sukodono tahun ajaran 2020/2021.

\section{METODE}

Penelitian tindakan kelas ini dilaksanakan di SD Negeri Gebang 2 Sukodono pada tahun ajaran 2020/2021. Subjek penelitian adalah guru dan peserta didik kelas III yang berjumlah 10 anak, terdiri dari 6 anak laki-laki dan 4 anak perempuan. Penelitian tindakan kelas ini dilaksanakan pada semester 2 tahun ajaran 2020/2021 selama \pm 6 (enam) bulan, dimulai bulan Januari 2021 sampai bulan Juni 2021. Data yang digunakan dalam penelitian ini berupa data kualitatif dan kuantitatif. Data kualitatif berupa penerapan metode mind mapping, dan keterampilan menulis ringkasan sedangkan data kuantitatif berupa hasil belajar peserta didik tema perkembangan teknologi.

Teknik pengumpulan data yang digunakan yaitu dokumentasi, wawancara, tes, dan observasi. Alat pengumpulan data yaitu dokumentasi kegiatan, pedoman wawancara, lembar tes, dan lembar observasi. Validitas data menggunakan triangulasi teknik dan sumber. Analisis data melalui reduksi data, penyajian data, dan penarikan simpulan.

Indikator keberhasilan penelitian yaitu ketuntasan minimal peserta didik pada keterampilan menulis ringkasan melalui metode pembelajaran mind mapping mencapai $70 \%$ dengan nilai KKM sebesar 70.00 .

\section{HASIL DAN PEMBAHASAN}

Penerapan metode pembelajaran mind mapping dalam usaha meningkatkan keterampilan menulis ringkasan tema perkembangan teknologi peserta didik kelas III SD Negeri Gebnag 2 Sukodono dilaksanakan dalam dua siklus. Setiap siklus terdiri dari dua pertemuan dalam pembelajaran tematik.

Sebelum dilakukan tindakan siklus I peneliti melakukan pembelajaran pra siklus untuk mengetahui tingkat keterampilan menulis ringkasan pada peserta didik kelas III SD Negeri Gebang 2 Sukodono. Hasil yang diperoleh 10\%, atau hanya 1 dari 10 peserta didik yang memenuhi KKM $(\geq 70)$. Data tersebut menunjukkan bahwa keterampilan menulis ringkasan kelas III SD Negeri Gebang 2 Sukodono masih sangat rendah. Faktor rendahnya keterampilan menulis ringkasan terlihat pada bagian pengungkapan isi ringkasan dan ejaan. Fakta tersebut mendorong peneliti untuk meningkatkan keterampilan menulis ringkasan peserta didik kelas III SD Negeri Gebang 2 Sukodono.

Pembelajaran dengan penerapan metode mind mapping tema perkembangan teknologi dilaksanakan dengan langkah-langkah: (1) guru memusatkan perhatian peserta didik dengan memberikan pertanyaan atau masalah melalui teks bacaan maupun tayangan video; (2) peserta didik mengidentifikasi isi atau inti informasi yang 
terkait; (3) menuangkan hasil identifikasi informasi dalam bentuk peta pikiran; (4) menjelaskan peta pikiran ke dalam bentuk paragraf singkat (ringkasan).

Setelah dilaksanakan pembelajaran dengan menerapkan metode pembelajaran mind mapping pada siklus I dan siklus II keterampilan menulis ringkasan peserta didik mengalami peningkatan. Hal ini dipengaruhi oleh terlaksananya urutan langkahlangkah pembelajaran mind mapping serta tahapan-tahapan menulis, yaitu sebelum menulis (prewriting), pengedrafan (drafting), merevisi (revising), mengedit (editing), dan pemublikasian tulisan (publishing). Sehingga memungkinkan peserta didik terlibat secara aktif dalam semua tahapan/proses penulisan, peserta didik belajar dari teman melalui tanya jawab, dan menggali informasi dari berbagai sumber dan media untuk membantu mencari kesalahan, memberi saran maupun masukan pada tulisan teman. Hal tersebut sejalan dengan pendapat Dalman (2014) bahwa menulis merupakan suatu proses yang kemampuan, pelaksanaan, dan hasilnya diperoleh secara bertahap, sehingga tidak dapat secara tiba-tiba langsung menjadi tulisan yang baik. Serangkaian keaktifan/tahapan tersebut memberi kesempatan kepada peserta didik memperbaiki tulisannya sampai mencapai taraf kesempurnaan.

Hasil rekapitulasi data penelitian tindakan kelas ini menunjukkan adanya peningkatan hasil keterampilan menulis ringkasan peserta didik kelas III SD Negeri Gebang 2 Sukodono pada prasiklus, siklus I, dan siklus II mengalami peningkatan. Peningkatan tersebut dapat dilihat pada tabel dan diagram berikut.

Tabel 1. Perbandingan Data Keterampilan Menulis Ringkasan Pra Siklus, Siklus I, dan Siklus II

\begin{tabular}{|c|c|c|c|c|c|}
\hline \multirow[b]{2}{*}{ Pencapaian } & \multirow[b]{2}{*}{ Prasiklus } & \multicolumn{2}{|c|}{ Siklus I } & \multicolumn{2}{|c|}{ Siklus II } \\
\hline & & $\begin{array}{c}\text { Pertemuan } \\
1\end{array}$ & $\begin{array}{c}\text { Pertemuan } \\
2\end{array}$ & $\begin{array}{c}\text { Pertemuan } \\
1\end{array}$ & $\begin{array}{c}\text { Pertemuan } \\
2\end{array}$ \\
\hline Nilai Tertinggi & 70.00 & 87.00 & 89.00 & 90.00 & 90.00 \\
\hline Nilai Terendah & 30.00 & 50.00 & 50.00 & 60.00 & 60.00 \\
\hline Rata-rata & 50.00 & 68.60 & 71.40 & 77.60 & 82.40 \\
\hline Ketuntasan (\%) & 10 & 40 & 50 & 80 & 90 \\
\hline
\end{tabular}

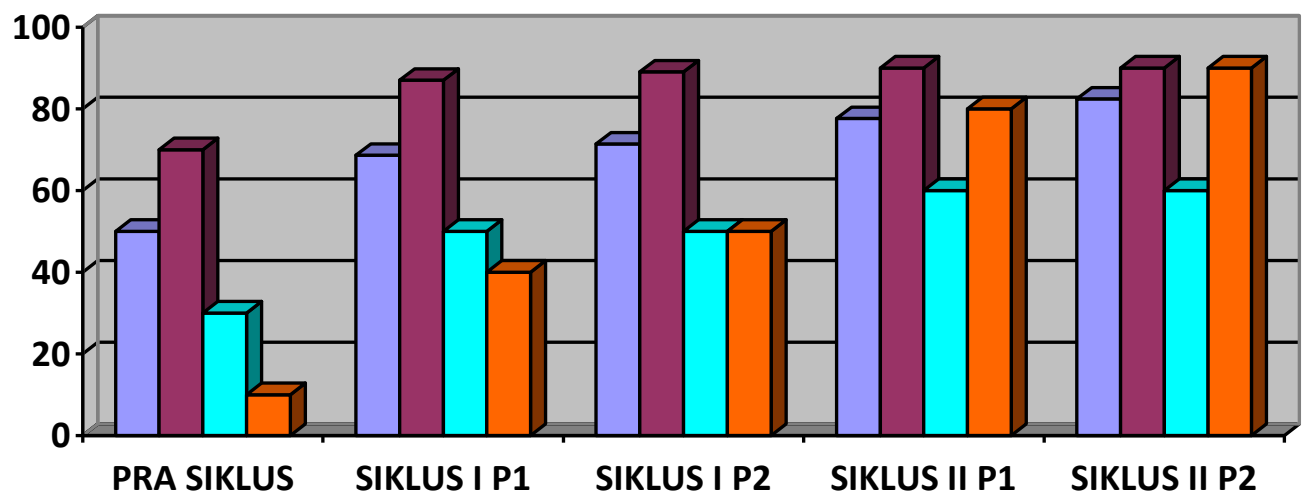

$\square$ Nilai Rata-Rata $\square$ Nilai Tertinggi $\square$ Nilai Terendah $\square$ Persentase Ketuntasan (\%)

Gambar 1. Garafik Perbandingan Data Keterampilan Menulis Ringkasan Pra Siklus, Siklus I, dan Siklus 
Berdasarkan tabel 1. dan grafik 1. di atas diketahui rata-rata nilai keterampilan menulis ringkasan peserta didik pada prasiklus sebesar 50.00, nilai tertinggi 70.00 , nilai terendah 30.00, dengan persentase ketuntasan sebesar 10\%. Data ini menunjukkan keterampilan menulis ringkasan peserta didik tergolong rendah dan tingkat ketuntasan juga masih sangat jauh dari standar minimal pembelajaran.

Pada siklus I pertemuan 1 terjadi peningkatan keterampilan menulis ringkasan pada peserta didik yang ditunjukkan dengan data. Berdasarkan data, diperoleh $40 \%$ peserta didik sudah mengalami ketuntasan belajar. Nilai rata-rata kelas yang diperoleh adalah 68.60. Secara individu nilai terendah peserta didik yaitu 50.00 sedangkan nilai tertinggi mencapai 87. Dari 10 peserta didik, 4 peserta didik atau $40 \%$ mengalami ketuntasan, sedangkan 6 peserta didik atau 60\% dinyatakan tidak tuntas karena mendapat nilai di bawah 70 atau KKM. Pada siklus I pertemuan 2 kembali mengalami peningkatan keterampilan menulis ringkasan pada peserta didik yang ditunjukkan dengan data. Berdasarkan data, persentase ketuntasan peserta didik naik $10 \%$ dari pertemuan sebelumnya $40 \%$ menjadi $50 \%$ dengan nilai rata-rata 71.40 . Secara individu nilai terendah peserta didik yaitu 50.00, dan nilai tertinggi mencapai 89.00. Dari 10 peserta didik, 5 peserta didik atau 50\% mengalami ketuntasan, sedangkan 5 peserta didik atau $50 \%$ dinyatakan tidak tuntas karena mendapat nilai di bawah 70 atau KKM. Penelitian dilanjutkan pada siklus 2, karena hasil keterampilan menulis ringkasan peserta didik melum mencapai indikator keberhasilan penelitian.

Pada siklus II pertemuan 1 nilai rata-rata dan persentase ketuntasan peserta didik dalam keterampilan menulis ringkasan mengalami peningkatan. Dari data hasil observasi, diketahui nilai rata-rata keterampilan menulis peserta didik mencapai 77.60 , dengan persentase ketuntasan $80 \%$. Hal ini juga terlihat dari hasil penugasan individu dengan nilai terendah 60.00, dan nilai tertingginya mencapai 90.00. Dari 10 peserta didik, 8 peserta didik atau $80 \%$ mengalami ketuntasan, sedangkan 2 peserta didik atau $20 \%$ dinyatakan tidak tuntas karena mendapat nilai di bawah 70 atau KKM. Peningkatan keterampilan menulis ringkasan peserta didik kembali terjadi pada siklus II pertemuan 2, yang ditunjukkan melalui perolehan nilai rata-rata keterampilan menulis ringkasan peserta didik mencapai 82.40 dengan persentase ketuntasan $90 \%$. Sedangkan bila dilihat dari perolehan nilai secara individu, hasilnya sama dengan perolehan nilai peserta didik pada pertemuan sebelumnya yaitu nilai terendah 60.00 , dan nilai tertinggi 90.00. Dari 10 peserta didik, 9 peserta didik atau $90 \%$ mengalami ketuntasan, sedangkan 1 peserta didik atau 10\% dinyatakan tidak tuntas karena mendapat nilai di bawah 70 atau KKM. Indikator keberhasilan penelitian sebesar $70 \%$ dengan KKM 70, sudah dapat tercapai pada kegiatan siklus II, sehingga tindakan penelitian dihentikan.

Hasil tindakan penerapan metode pembelajaran mind mapping untuk meningkatkan keterampilan menulis peserta didik ini sudah terbukti dari penelitianpenelitian sebelumnya, seperti penelitian yang dilakukan oleh Suwarti (2018) pada peserta didik kelas V SDN Majenang 2 Sukodono. Hasil penelitian menunjukkan bahwa terdapat peningkatan keterampilan menulis dan hasil belajar yang dibuktikan dengan perolehan skor rata-rata nilai akhir yang diperoleh dari rata-rata nilai kemampuan menulis dan nilai hasil belajar Tema 7 pada tiap siklus adalah 73,03 ; 83,$75 ; 88,80$ dengan persentase ketuntasan 48,00\%; 68,00\%; 80,75\%. Sri Maryati (2019) juga melaksanakan tindakan penelitian pada peserta didik kelas V semester 2 tema 8 SDN Newung 3 Sukodono. Hasil penelitian menunjukkan bahwa terdapat peningkatan keterampilan berpikir kritis dan hasil belajar yang dibuktikan dengan perolehan skor rata-rata nilai akhir yang diperoleh dari rata-rata nilai kemampuan berpikir kritis dan nilai hasil belajar Tema 8 pada tiap siklus adalah 72,$11 ; 83,28 ; 91,13$ dengan persentase $43,75 \% ; 68,75 \% ; 82,50 \%$.

Hasil tindakan penelitian Dinda Ayu Septiani (2019) juga menyatakan bahwa metode pembelajaran mind mapping dapat meningkatkan keterampilan menulis 
ringkasan peserta didik kelas IV B SDN Cemorokandang 2 Kota Malang. Hasil ratarata nilai dan persentase ketuntasan peserta didik dalam menulis ringkasan mengalami peningkatan tiap siklus, yaitu 44,15 dengan persentase ketuntasan $10 \%$ pada pra siklus, pada siklus I rata-rata nilai peserta didik adalah 61,25 dengan persentase ketuntasan 50\%, dan pada siklus II rata-rata nilai peserta didik dalam menulis ringkasan adalah 77,05 dengan persentase ketuntasan $80 \%$. Hal ini tentunya sejalan dengan penelitian yang dilakukan oleh peneliti yang sama-sama menggunakan variabel mind mapping untuk meningkatkan keterampilan menulis peserta didik.

\section{SIMPULAN}

Berdasarkan hasil penelitian tindakan kelas terkait keterampilan menulis ringkasan tema perkembangan teknologi pada peserta didik dapat disimpulkan bahwa penerapan metode mind mapping dapat meningkatkan keterampilan menulis ringkasan tema perkembangan teknologi pada peserta didik kelas III SD Negeri Gebang 2 Sukodono tahun ajaran 2020/2021. Peningkatan keterampilan menulis ringkasan peserta didik dapat kita lihat dari nilai rata-rata awal (pra siklus) 50.00 naik menjadi 82.40 pada siklus II pertemuan 2 dan persentase ketuntasan awal hanya 10\%, naik menjadi $90 \%$ pada siklus II pertemuan 2 setelah diterapkannya metode pembelajaran mind mapping.

Implikasi hasil penelitian ini secara teoretis, dapat dijadikan sebagai referensi dalam penelitian lebih lanjut, serta dapat memperluas pengetahuan pembaca tentang inovasi pembelajaran, sedangkan secara praktis dapat dijadikan sebagai alternatif guru untuk meningkatkan keterampilan menulis ringkasan peserta didik pada pembelajaran menulis.

Saran bagi peneliti yang menggunakan variabel mind mapping perlu diadakan penelitian serupa dengan meninjau aspek lain dari kualitas pembelajaran sehingga dapat diketahui sejauh mana efektivitas implementasi mind mapping untuk meningkatan keterampilan menulis peserta didik pada jenis karangan lain.

\section{DAFTAR PUSTAKA}

Arikunto, S. (2014). Prosedur Penelitian Suatu Pendekatan Praktik. Jakarta: Rineka Cipta.

Buzan, T. (2011). Buku Pintar Mind Map. Jakarta: PT Gramedia Pustaka Utama.

Dalman, H. (2014). Keterampilan Menulis. Jakarta: PT Raja Grafindo Persada.

Depdiknas. (2003). Undang-Undang Nomor 20 Tahun 2003. Tentang sistem pendidikan nasional.

Dosen Pendidikan 2. (2021). Penjelasan mind mapping. Diakses dari https://www.dosenpendidikan.co.id

Emzir. (2011). Metodologi Penelitian Kualitatif Analisis Data. Jakarta :PT Raja Grafindo Persada Pusat.

Maryati, Sri. (2019). Peningkatan Kemampuan Berpikir Kritis dan Hasil Belajar Peserta didik pada Tema 8 Lingkungan Sahabat Kita melalui Metode Pembelajaran Mind Mapping di SD Negeri Newung 3. Sragen.

Rubiyanto, R. (2011). Metode Penelitian Pendidikan. Surakarta: Qinanty.

Septiani, D.A. (2019). The Improvement of Summary Writing Skill Through The Learning Model of Mind Mapping for Fourth Grade of State Elementary School of Cemorokandang 2 Malang. Thesis.Bachelor Program - Primary School Education, Department of Primary and PreSchool Education, Faculty of Education, State University of Malang. Advisors: (I) Dra. Ratna Trieka Agustina, S.Pd., M.Pd., (II) Yulia Linguistika, S.Pd., M.Ed.

Sukartiningsih, dkk. (2013). Peningkatan Keterampilan Menulis Narasi Ekspositoris Melalui Jurnal Pribadi Siswa Kelas IV Di SD Negeri Balasklumprik 1/434 Surabaya. Jurnal PGSD Universitas Negeri Surabaya. 
Volume 9 Nomor 1 Tahun 2021

Suwarti. (2018). Penerapan Metode Pembelajaran Mind Mapping untuk Meningkatkan Kemampuan Menulis dan Hasil Belajar pada Tema 7 Peristiwa dalam Kehidupan di SD Negeri Majenang 2. Sragen.

Tahir, M. (2012). Pengantar Metodologi Penelitian Pendidikan. Makassar: Universitas Muhammadiyah Makassar.

Wina, S. (2016). Strategi Pembelajaran Berorientasi Standar Proses Pendidikan. Jakarta: Prenadamedia Group.

Wiraatmadja, R. (2009). Metode Penelitian Tindakan Kelas untuk Meningkatkan Kinerja Guru dan Dosen. Bandung: PT Remaja Rosdakarya offset. 